\title{
リポソームの動的構造を見る
}

\author{
宝 谷 紘 - \\ 京都大学理学部生物物理学教室 $\mathbf{T} 606$ 京都市左京区北白川追分町 \\ 昭和 61 年 6 月 21 日 第 47 回 膜研究会 京都大学工学部にて講演
}

\section{Transformation of Liponsomes Revealed by Dark-field Light Microscopy}

\section{Hirokazu HotANI}

Department of Biophysics, Faculty of Science, Kyoto University, Kyoto 606

\begin{abstract}
Liposomes undergoing transformation were visualized by real time dark-field microscopy in order to study the role of lipid in morphogenesis of biological vesicular structures. Liposomes were found to transform sequentially in a well-defined manner through one of several transformation pathways. A circular biconcave form was an initial shape in all the pathway and it transformed into a stable thin flexible filament or small spheres via a variety or regularly shaped vesicles which possessed geometrical symmetry. The transformation was reversible up to a certain point in each pathway. Osmotic presure was found to be the driving force for the transformations. Biological membrane vesicles such as trypsinized red cell ghosts also transformed by similar phthways.
\end{abstract}

Key words : Liposome, Dark-field microscopy, Transformation, Form, Red cell

膜器官は多様な形をしている

脂質が自己集合して膜になる

水溶液中のリポソームを光顕で見る

映画：ダイナミックリポソーム

リポソームは順次的に形態変換する

浸透圧の変化が形態変化の原動力である

赤血球型は安定な形である

順次的形態変化は膜に普遍的性質である

御招介有難うございました。私は生物現象を分子レベ ルで見ることに昔から興味がありまして，てのでろは あっぱら“何んでも見てやろう”の精神に徹しているわ けです. 今回の演題は「リポソームと微小管」だったの で，ての演題を見られた方はこの両者にどんな関連があ るのか疑問をもたれたと思います．まあ生体膜には裏う ちタンパク質が何種類か有り，その主成分の一つが微小 管なので関連はあるのですが, この会は膜の研究会なの
で微小管自身の話はもう一つピッタリと来ないので, 本 日はリポソームに話を絞らせていただきます.ダイナ ミックなポリソームの性質を見ていただくためには映画 にまさるあのはありません. そてで, 話の途中で 10 分間 づつの映画を 2 本ほど上映しながら，お話を進めてゆき たいと思います.

\section{膜器官は多様な形をしている}

Fig. 1 は皆さんよく御存知のいろいろな種類の細胞で す.てのような様々な形がどのような仕掛で生じてくる かという点がこの拈話の興味の中心です．乙れらの細胞 の形はそれぞれずい分と違っています．乙の神経細胞の 場合, 本体自身は一般的な形をしています. 特徵的なて とは, それに大変細長い突起状の管状線維が生えている ことです．筋肉の細胞は細胞自体の形が細長い線維状に なっています．とにかく細胞の形は多様性に富んでいま す．ところで細胞は膜で囲まれております，したがって 細胞の形はある程度膜の性質によって決められているの 

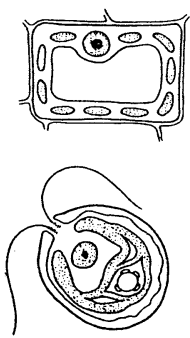

8

(i.)
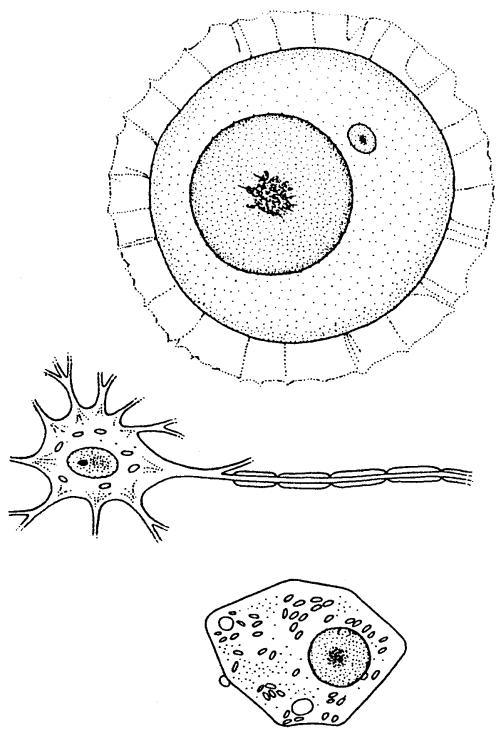

Fig.1 細胞のさまざまな形

ではないかと考えられます。

一方, 細胞の中味を見ますと, 核やミトコンドリアや ゴルジ体, あるいはエンドプラスミックレティキュラム 等の様々な種類の細胞内器官が見えてきます．乙れらは ほとんど膜から出来上っている構造なのです。つまり, 細胞全体は膜に囲れ，その中身の細胞内小器官むほとん ど膜器官ということになります，とてろが，乙の臟器官 は各々特異的な形をしているのです。形態学者はその形 を見れば「てれはゴルジ体である」とか「てれはミトコ ンドリアである」とわかるわけです，とてろで, 各々の 細胞内器官はそれぞれに特異的な機能を営んでいます. このととは逆に言えば機能にとって形態が大切な役割を 果たしているてとを意味します。てういうわけで, 膜構 造がどのようなメカニズムによってその形を構築するの かという疑問が興味をひくわけです.

\section{脂質が自己集合して膜になる}

膜構造を観察し始めた歴史はずっとさかのぼります。 Fig. 2 は 1904 年に出版された O. Lehmannの「液晶」1) という本から引用したものです. この本は世界中の図書 館に現在 3 冊現存していることがわかっています．私が 数年前にイエール大学におりました時に, なんと地質学 教室でこの本をみつけました。つまり, 前世紀の末には すでに, 脂質を水の中に入れるとての絵に示されたよう な構造が生じてくることを当時の偏光顕微鏡によって観 察していたのです．ててに見えているものは多重層のい

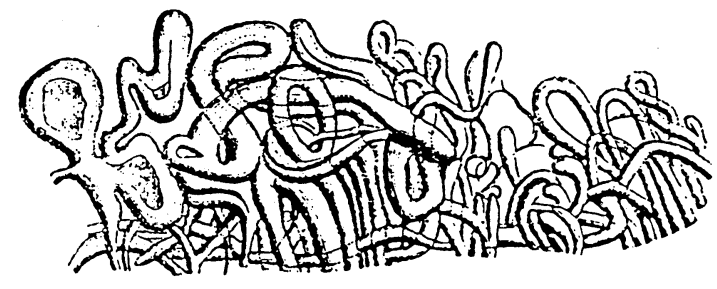

Fig. 2 ミエリン像. O. Lehmann の“液晶” ${ }^{11}$ より

わゆるミエリンフォームとかミエリンフィギュアーと呼 ばれるあのですが，扔そらくこれを見た人はこんな荒唐 無けいなすのはサイエンスにならないと考えたのでしょ う.でく最近までてれらの形態を真剣伍研究しようとす る人はあらわれませんでした。

広い意味でリポソームといえばてれらのミエリン フォームも含むわけですから, リポソームの形態を研究 する際には対象を吟味しないとすのすでく複雑な問題に なってしまいます，例えば，生体膜をそのまま扱抢うと すると, 脂質だけを考えてみましても, たくさんの種類 の脂質の混合系を調べるととになります．したがって， 扱う系の組成をあう少しシンプルにすればなんらかの法 則性が見えてくるのではないかと考えたわけです.

一方, 形態形成の問題を考える時, タンパク質が多数 集合して球形や棒状あるいはもっと複雑な形態を作り出 すメカニズムが参考になるのではないかと思ったので す. タンパク分子の場合には個々の分子が, 出来上った 構造汇関する情報を持っているので, 構成タンパク分子 の溶液を適切な条件にしてやればそれらの分子がつぎつ ぎと自動的に集合し，全体の構造がひとりでに出来上り ます．このメカニズムを一般にセルフアセンブリー, 日 本語では自己集合と呼んでいます，脂質の場合む，水中 で脂質分子が集合して二分子層膜を形成する過程は完全 にセルフアセンブリーですから，ての考え方をさらに延 長してリポソーム全体の形にも適用出来ないかと考えた わけです。管状や球形やさらに複雑な形む脂質分子自身 にある程度のインフォメーションが含まれていて自動的 にそれらの形態が生じてくる可能性を調べたいのです. そのためには，さきに述べましたように，出来るだけ簡 単な系がよろしい，そてで DPPCとコレステロールだ けから成る系を調べるととにしました．リポソームを作 る方法は普通一般に使われている方法でして, 有機溶媒 に溶けている脂質混合物を窒素ガス流でドライアップし た後, 水を加えるという方法です. 


\section{水溶液中のリポソームを光顕で見る}

Fig. 3 は，てうして作ったりポソームを電子顕微鏡に よってネガティブスティニング法で見たものです．どて の教科書にあ載っているような多重層が観察され, 全体 の形は球状が少々ゆがんだあのが多いのです．とてろ が, 後で見ていただきますが, 同じ試料を光学顕微鏡で 見ると全く異なった像が見えてきます。つまり染色・乾 燥したリポソームと溶液中のそれとは形態的に大きく異 なります。このことは, 考えればあたりまえのことで す。つまり, 脂質二重層は水があってはじめて形成され る構造ですし, 厚さ $5 \mathrm{~nm}$ のよなうすい膜から成る全 体の大きな形態が乾燥後む保たれていると期待するてと がはじめから無理な話なのです，そてで我々は，溶液の 中でのリポソームの形をあるがままに見る方法として高 輝度暗視野光学顕微鏡法を用いるとととし, それを改良 しました．さきに述べました前世紀の光顕法でリポソー ムを見ても，さすがにうまく見えません，今見ているリ ポソームが, 多重層ではなく単層であることに原因があ ると思われます。暗視野光顕法あ古い歴史をむっていま すが, 改良によってきわめてパワフルになり, 再び脚光 をあびつつある方法です (Fig. 4). 改良の要点は高性 能コンデンサーときわめて高輝度の光源が使えるように なったてと．そして超高感度ビデオカメラによってダイ ナミックな映像の記録が出来るようになったてとです. 他のいろいろな光顕法を試みましたが, 膜は薄い構造で すから，なかなか良いコントラストが得られず，結局り ポソーム観察には暗視野法につきるという感じです。

映画 : ダイナミックリポソーム

こてで映画にいたします。暗視野像は目では大変はっ きりと見えるのですが，それであ映画フィルムに直接撮 影するためには暗いのです，乙の映画はビデオ画面を映 画にしたあのです．溶液中ではリポソームはどのような 形をしているのかをまず見ていただきます。まず一種類 の脂質から成る一番簡単なりポソームですが，乙れは DMPCのみで出来ています. 相転移温度より高い $30^{\circ} \mathrm{C}$ 近辺で観察しているので, 長く滑らかで柔い管状になっ ています．次のシーンはやはり単純な組成のリポソーム で, DPPCのみから出来ています，乙の場合は相転移 温度が $44^{\circ} \mathrm{C}$ 附近なので, $50^{\circ} \mathrm{C}$ 近辺で観察しています. やはり柔らかくて滑らかな線維状の管になります．次の シーンはDPPCリポソームを相転移温度より低い温度
膜 (MEMBRANE)，Vol.12 No.5 (1987)

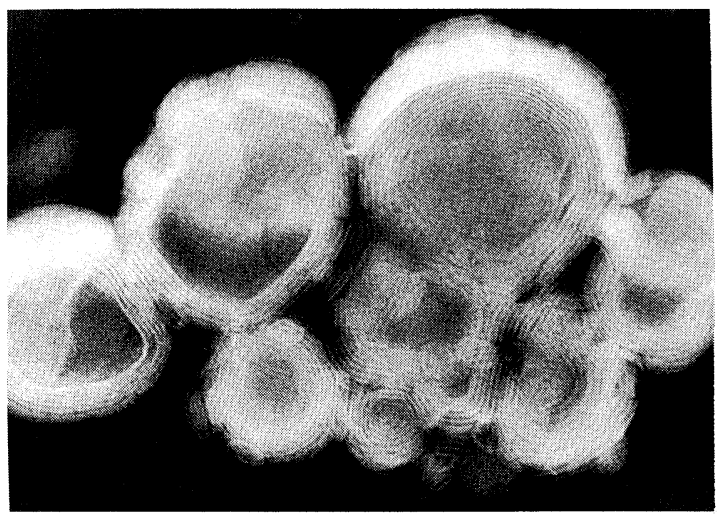

Fig.3 リポソームの電子顕微鏡像. スケール:0.1 $\mu \mathrm{m}$

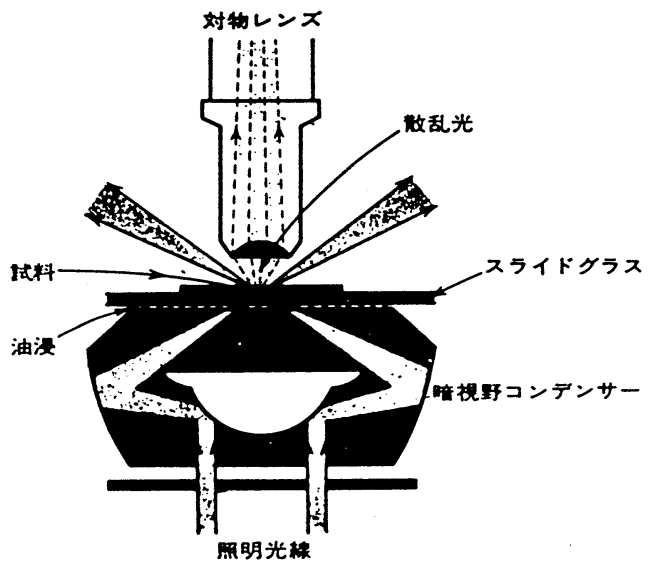

Fig. 4 暗視野光学顕微鏡法

で見たものです．先程の柔い線維が極端に硬くなり，折 れ曲り、ゴッゴッしたセグメントのつながりに変化して います．脂質二重層が液晶相から結晶相に転移したもの です．目で見る相転移というわけです，次ぎのシーンは DPPC とコレステロールのモル比 $1: 1$ の混合物から 出来たりポソームです. DPPCにコレステロールを加え てゆくと相転移温度が下がるとみえて, $30^{\circ} \mathrm{C}$ 前後でも 滑らかで柔いリポソームを形成します，乙の場合は管状 というよりあ割合規則的な形のさまざまな小胞状りポ ソームが多く出来てきます．乙のシーンにはピーナッ形 や赤血球形, あるいは四角板状の頭に管状の尻尾が着い たむのとか, 三角板状とかいろいろな小胞が見えていま す.

次は複雑な組成をむつ脂質の例としてエッグレシチン から成るリポソームが映っています. 大変柔らかく細長 
い線維状の管が出来ています．ての中には 2 種類の太さ のあのが見えています．太いものと，細くて大変柔かく 激しく曲げブラウン運動をしているものです．各々の 1 本の線維については太さは均一で途中から太さが変わっ ていくことはありません，一般的に言えば生体から抽出 された脂質は非常にフレキシブルな線維状リポソームを 作りやすい傾向があります，乙れは脂質組成が複雑なの で流動性が高くなっているからだと推察されます。

てのシーンはエッグレシチンの大きな固りの表面を見 ています。つまり，リポソームが形成される過程を見た いのです．脂質の固まりの表面から様々の形の管が飛び 出しているのがわかります，中には枝分れしている管も あります。それらがちぎれて小胞が形成されています。 脂質表面ではきわめてドラスチックなてとが次ぎ次ぎと 起てっています，中にはてのような数珠状のあのが出来 てきます．ところがてれをたどってゆくと少しずつ連続 的に変化し，やがて数珠がはっきりしなくなり，てちら の端では単なる管になっています，中程では管に多数の くびれが生じて数珠状になったり, あるいは逆の過程で 管になったりして形態がゆらいでいます，数珠が更に進 行すると一つづ外れて，小さな球状小胞になるのです。

つまり, 脂質の固まりからは様々な形のダイナミック な構造が生じ, それらが安定な形へと形態変化している のです。一つ一つを見るとミトコンドリアに似ていると かゴルジ体に似ているということです。また，神経線維 等の基本構造は細長い管ですから，脂質自体が自然汇神 経管様構造を作り上げる能力を持っていると考えること あ出来ます。こてで映画を中断してスライドにもどしま す.

\section{リポソームは順次的に形態変換する}

映画の中にあ出て来ましたが，DPPC とコレステロー ルの混合モル比を変えた時のリポソームの形が Fig. 5 とFig.6亿示されています. 100 ：5 と,コレステロー ルが少ない時には脂質はほとんど固まりのままでリポ ソームがうまく形成されません，あちろん常温での話で すが. 以下の実験は全て常温で行っています. 100：20 になると Fig. 5でわかるようにかなり柔らかくなり，少 し形がいびつですが管や小胞状りポソームが出来てきま す. Fig, 6はモル比 1：1のリポソームです. 幾何学的 対称性をむった美くしい小胞状の柔らかいリポソームが 出来ています.

とてろでこのモル比 1：1のリポソーム試料を観察し
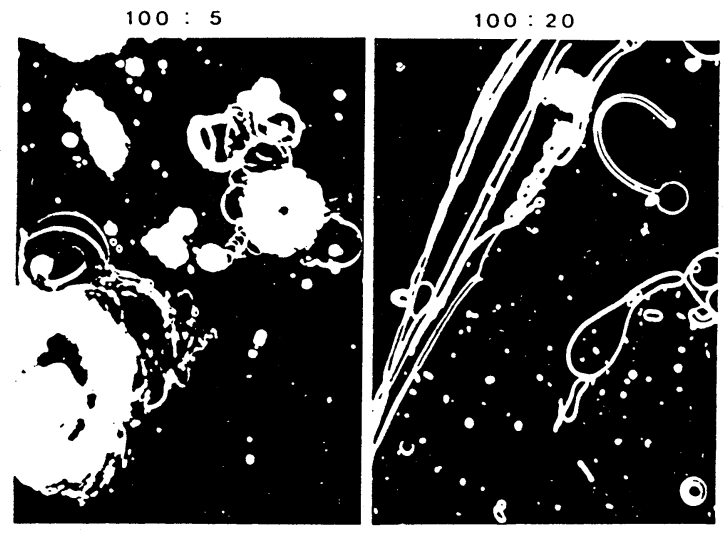

DPPC - Chol

$50 \mu \mathrm{m}$

Fig. 5 DPPC とコレステロールから成るリポソー 厶. 写真上部の数字は組成モル比

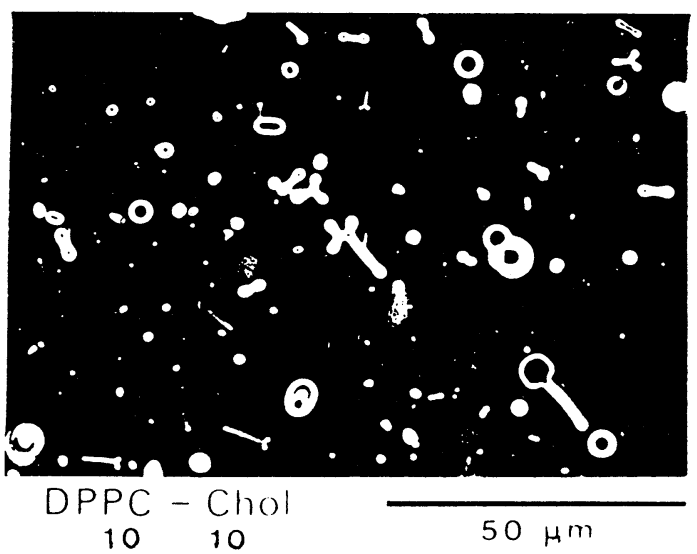

Fig.6 DPPC : コレステロール =1 : 1 (モル比) のリポソーム

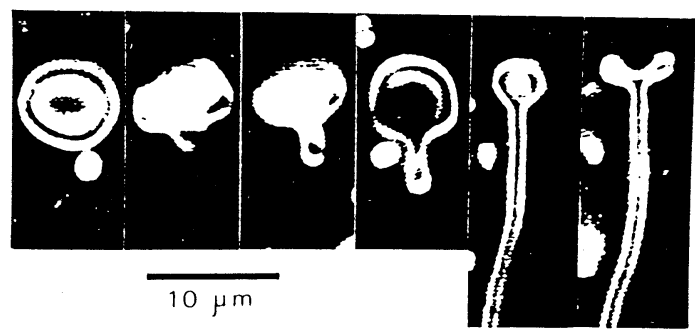

Fig.7 リポソームの経時的変化

ていると, 時間とともにどんどん形態が変化してゆくこ とがわかりました．Fig. 7 はその一例です．赤血球状小 胞が枝分れした管状へと形態変化しています。乙れらの 詳しい変換過程については後ほどすう一度映画で見てい 
ただきます. 1 個 1 個の変換過程を観察していますと, 全部の小胞が同じ過程を経るのではなくて, 各々が特異 的な形態変化をしているととがわかりました ${ }^{2,3)}$. しか し, 最初の形はいつも赤血球型です.つまり円盤状で, まん中がくぼんでいるのです．直径は 1 〜 $10 \mu \mathrm{m}$ です. その後, これらが, 様々な経過をたどるのですが, 最後 にはきわめて細い柔い線維状か小さな球状かどちらかに 落ちつくことがわかりました. 赤血球型から最終型へ変 化するし方, いいかえれば, リポソームの形態变換パス ウエイが数種類以上あるのです．それをまとめたあのが Fig. 8 です. 左端に示した赤血球型のみ正面からの 2 方 向から見た図が示されています.

赤血球型は正面から見ると円形なのですが, 時間とと あに円形がゆらぎはじめ, Fig. 8亿見られるでとく，五 角形になったり四角形, 三角形あるいは二角形に変化す るのです，あちろん二角形はありませんから，実際上は 楕円形に見えます. 円形から多角形に変化する段階でパ スウエイが大きく分岐するわけです. 実際の変化の様子 は最後に映画で見ていただきますが，てれらのバスウエ イは一見まとめようのない形態変換が起てっているよう に思えますが実は割合と規則性高く進行してゆく事象で あることが解りました。

とり合えずFig. 8 の最下段にそって進む五角形パスウ エイについて説明します.より詳しい移行過程が Fig. 9 中の写真で解っていただけると思います. 出発点である 赤血球型は正面から見るときれいな円形をしています が，まずその円形がゆらぎはじめ多数の振動モードの混 ざった運動をし，やがていずれかの多角形に落ちつきま す. 今の場合は五角形というわけです. そのうち五角形 の角の部分がどんどん鋭くなり, 辺の部分が内側へ落ち てみはじめ, やがて角が臨界的に突出して管が形成され ます．その後, 管がどんどん長くなりその分, 頭の部が 小さくなってゆきます，ある程度頭が小さくなると，残 りの角から管が突出して, 枝分れした管状になります. 時間と伴に管はますます長く, 細く, 柔くなって線維状 になり, 時には小さな頭の部分からむう一度劇的な変化 が起とり, 二重の球になったりします。二重であるとと は何故わかるかといいますと. 最初の赤血球型の時の表 面積は計算できています.一方最終の球の表面積むすぐ 計算できるのですが, それが最初の表面積のちょうど半 分になっているというわけです。

Fig. 9 の黒丸は形の変化に伴う表面積の值を目屯って いますが，形はずいぶん変化しても一定に保たれていま

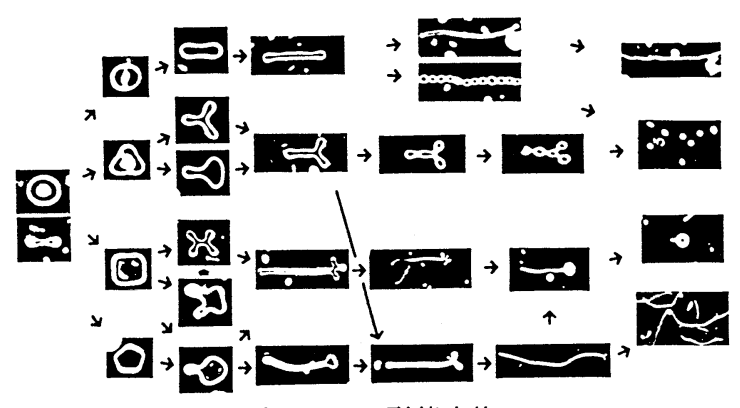

Fig. 8 リポソームの形態変換パスウエイ

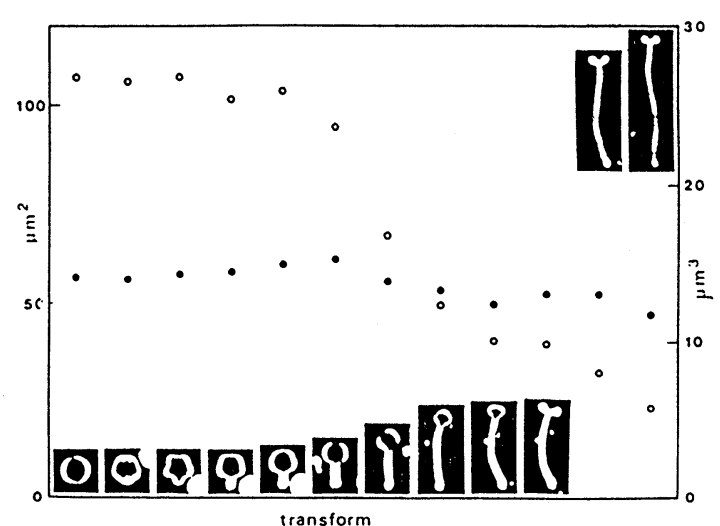

Fig.9 五角形パスウエイに打ける体積 $(\bigcirc)$ と表面 積 $(\mathbf{O})$ の变化

す．一重の膜である限り面積は一定に保たれているので す. 二重膜になると光散乱能は一桁近く増大するので, 上記の球は一重膜の球に比べてきわめて明るく輝くの で，暗視野光顕で簡単に区別がつきます．乙れ屯暗視野 光顕のメリットの一つです.

話がわき道にそれましたが, 他の四角形, 三角形につ いても基本的には同様の形態変化が進行しているので す6. それぞれの多角形の角の突出がくりかえされて枝分 れした管状になり，その一つの管がどんどん長く細く柔 らかくなって線維状になるのです，二角形にあたる楕円 パスウエイでは角が突出すると同時にピーナッ状にな り、乙れが管の連らなった形に対応しているわけです。 各パスウエイに見られる他の道は，枝分れした管に括れ が入って, それが深くなり数珠状に変化し, やがてそれ らがバラバラになって小さな小球リポソームになるてと ああります．最終的なリポソームの形態が小球になるか 線維状になるか, 乙れを区別している機構については全 く手つかずの課題です. 

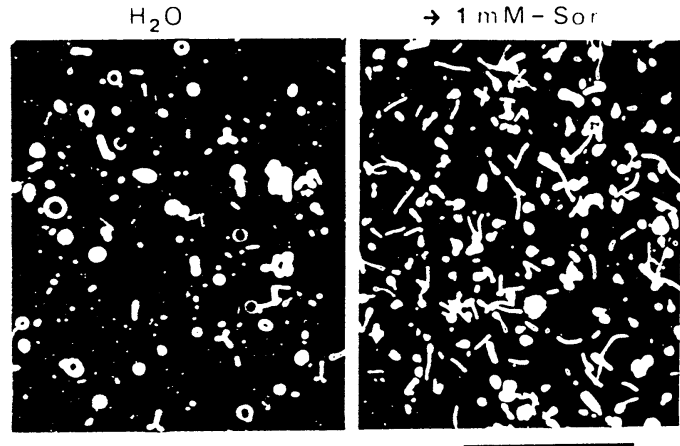

$50 \mu \mathrm{m}$

Fig. 10 ソルビトールによって浸透庄を上げた時に 生じるリポソームの形態変化

\section{浸透圧の変化が形態変化の原動力である}

次に興味ある問題はこれらの形態変化を進行させる原 因は何であるかということです．とてろでての変化は試 験管内で保存したリポソームには見られません．ての試 料を光学顕微鏡で観察しているとどんどん変化してゆく のです. しかし光や熱でての変化が生じているのではあ りません．そてで变化の要因になりそうなものをかたっ ぱしから試してみました。膜にはカルシウムがいかにも 効きそうですからまず最初に試しました。なるほど, ちゃんと変態変化を起こします．続いて様々な塩類を試 すと全部効くのです．糖類を加えても変化します.

何を加えてあ効くというととは化学的作用によって効 いているのではなく, 物理的作用によっているのだと考 えるのが自然です. 要するに浸透圧が効いているのだと 思われます. そこで浸透圧調整剤であり, 化学的には何 ら反応性のないソルビトールを加えてリポソーム溶液の 浸透圧を水から $1 \mathrm{mM}$ 亿上昇させると様々な小胞状りポ ソームは瞬時にして小球か又は線維状の最終形態へ変化 していました。その様子は Fig.10䎲示されていま す (Fig.10). 左図のような小胞状りポソームがソルビ トールを添加して浸透圧を上げると右図のような最終形 態になるのです．しかし，ひょっとすると浸透圧として ではなくソルビトール自身が効いている可能性もなきに

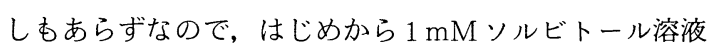
でリポソームを調製しました，そうすると，水中と同じ く小胞状リポソームが出来ました。 そこで更にンルビ トールを加えて $5 \mathrm{mM}$ 亿濃度上昇させると, やはり線維 状と小球状の最終形態に変化してしまいます。つまり, 形態変化の要因はソルビトールの化学的作用ではなく,

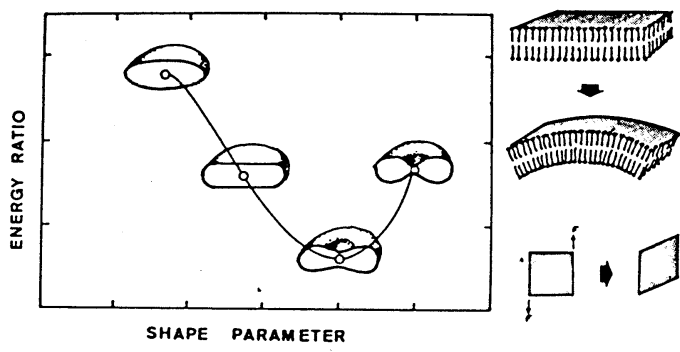

Fig. 11 様々な形態の円盤状小胞の曲げ弾性エネル ギー. Canham ${ }^{4)}$ の図を改変

浸透圧の変化なのです.

先に述べた顕微鏡で 観察中に生じる形態変化の場合は 特に浸透圧を上昇させるような操作は行っていません. しかし, 以上の事実を考慮すると, 光顕観察中の試料か らゆっくりと水分が蒸発し, 試料中にわずかに存在して いた塩分が濃縮され, リポソームの内外浸透圧差が生 じることが形態変化の要因だと思われます．乙れを確か めるために小胞の表面積と体積を測定するととにしまし た. 光学顕微鏡によって小胞の三次元的形態が映像とし て記録できるので少々複雑な形でもその表面積と体積を 計算によって求めるてとが出来ます.五角形パスウェイに おけるこれらの值の変化が Fig. 9に示されています. 形 態変化に伴って体積はどんどん減っていますが, 表面積 の方は打打む称一定に保たれています。予想通り，浸透 圧差によってリポソーム中の水が膜を通過して外へ出る ために体積が減少しているのです．表面積はとりむなお さず膜の面積ですから, 少々リポソームの形が変わって あ一定に保たれるわけです。他のパスウェイについてす 同様の測定を行いましたが, いずれも体積減少, 表面積 一定の結果が得られました。

\section{赤血球型は安定な形である}

以上の結果から形態変化の原動力がリポソーム内外の 浸透圧差であることがわかりました，次の興味は赤血球 型や多角形盤型などの形がどのような仕掛で自然に生じ てくるかということです．膜小胞の形に関して歴史的に 古くから注目を浴びてきたすのに赤血球があります。一 見, 奇妙で美しく, 大きさあきっちり決まっていて, し かむ何時であ手に入る材料ですから興味をひいたのは あっとあなととです．百年以上の長きにわたってての美 くしい形の生ずる機構について様々な説が出されてきま したが，今だに決定的な説はありません．その中の一説 
ですが，1970 年に Canhamという人が出した説がリポ ソームの形を理解する上にきわめて重要だと思われま す4).

アイデアのエッセンスは膜を二次元に広がった液晶と 見なすことです．液晶だとすればFig. 11 の左下に示し たようなずり変形に対しては弾性エネルギーの蓄積はゼ 口で右上に示した曲げの変形に対しては, 膜は極度に薄 い構造だといえごあ弾性はあるはずです。そてで赤血球 と同じ体積と表面積を与えて, この条件の中で小胞の形 を変化させ, 立体的に曲げによる全弾性エネルギーを計 算するのです，その結果が Fig. 11 なのです．曲げエネ ルギーは曲率の 2 乗に比例します．したがって，曲がっ ている部分の多い赤血球型の方が, 平面の多いパンケー キ型より弾性エネルギーが高いように思えます。とてろ がFig. 11 で見られるでとく, 赤血球型の方が安定に なっています，理由はこうです．赤血球型ではまん中の 部分をへこませるてとによって体積を減少させ，余った 体積を周辺部へまわします，その結果周辺部の曲率が小 さくなり, 周辺部の弾性エネルギーが大きく減少し, さ しひきすればパンケーキ型よりエネルギーが低くなると いうわけです，つまり，赤血球形にするための特別な仕 掛があるのではなく，一定の体積と表面積を与えれば膜 小胞は一番安定な形として自然に赤血球型になるという ことです.

てのような考え方を強く支持する，簡単ではあります がエレガントな実験が Bull ${ }^{5)}$ にっって行われました。

Fig. 12 亿示したように赤血球膜の一部分をガラス表面 に固定するのです。そして赤血球上にレーザーによって 小さな印を着けます．乙の赤血球を粘性流を使ってゆっ くりと押すのです．そうすると:Fig. 12 亿示したように, 固定部分を残して他の部分は移動します。しかむ, 全体 の赤血球型を保ったままです．乙の移動は図佂示されて いるように可逆的です，つまり，印をつけられた部分は 周辺部でも，まん中のくぼんだ所であ，どんな曲率でも とることが出来るのです，乙の事実は昔から根強くあっ た, 赤血球の内側に比較的固い裏うちタンパクのケージ のようなものがあって，てれが形を規定しているという 考え方を否定します．赤血球の形は各部分の曲率を決め る方式ではなく全体の安定性によって決められているの だと思われます。

\section{順次的形態変化は膜に普遍的性質である}

それでは赤血球膜も DPPC・コレステロールの系と

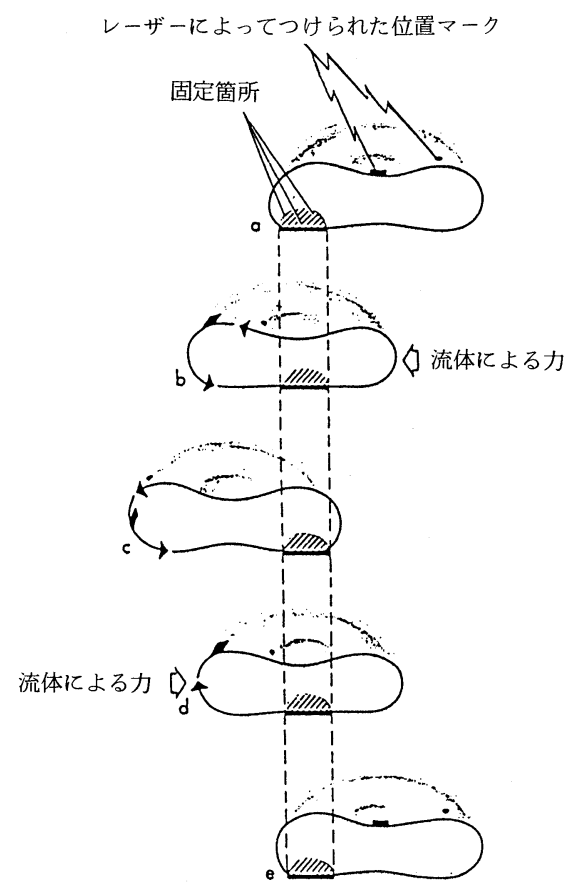

Fig. 12 赤血球の粘性流による変形 Bull $^{5)}$ の図を改変

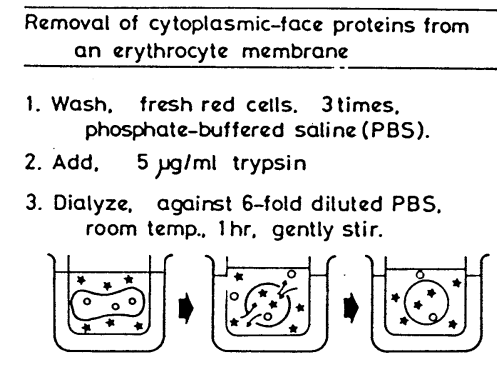

4. Wash, 1/6-PBS, 10 kr.p.m., $15 \mathrm{~min}$.

Fig. 13 赤血球の裏うちタンパク質を分解する方法 ○はへモグロビンを，丸はトリプシンを示す

同様の形態変換をするでしょうか？いきなり赤血球溶 液の浸透圧を上げたのでは金平糖型になるだけで，変換 パスウエイに沿ったような変化はしません．赤血球の内 側には, 膜の機械的強度を上げるために裏うちタンパク 質がたくさん付いています。乙れらが，赤血球膜の本来 あっている性質を発輝させにくくしているのだろうと考 えたわけです．Fig. 13のような方法で赤血球内側の裏 うちタンパク質をトリプシン分解で除きました。ての ゴースト赤血球膜小胞の浸透圧を上げてみると, Fig. 14 に見られるように，DPPC・コレステロール系と同じ形 

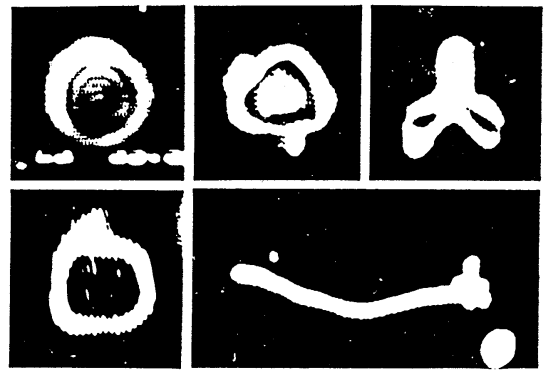

from Red Cell

Fig. 14 裏うちタンパク質を除いた赤血球の形態変化

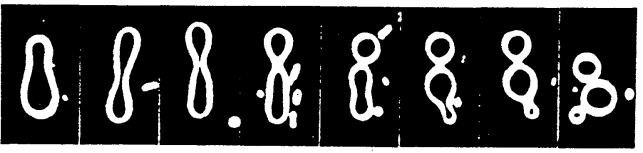

Division of a liposome

$4 \mathrm{~min}$

Fig. 15 リポソームの分裂過程

態変換が生じました，他の脂質膜について屯調べてみま した，例えば,ディノフラジェレートという最も下等な 単細胞生物から抽出された脂質を用いて作ったりポソー ムも同様の順次的多形変換を示します。

更に驚くことには，脂質様物質として有機合成された ある種の両親媒性分子が膜小胞を形成し，てれありポ ソームと同様の形態変換することが明らかにされたので す 5,7$)$. つまり, 膜小胞の多形変換する性質は, 脂質膜 の範囲を超えて, より一般的な二次元液晶膜の特質とし てとらえることが出来るといえます．

話を元にあどしますが，形態パスウエイにおける赤血 球型以降の多角形への変化む上記に述べたの之同じ原理 によって説明可能だと考えています。つまり表面積一定 で体積を減らしていった時の曲げエネルギーを計算する 問題に還元しょうというわけです．この問題は意外に難 しく, 緒についたばかりです.

いろいろな細胞内器官や赤血球の形, また神経細胞の 軸索突起のような細長い管状構造む,リポソームで見ら

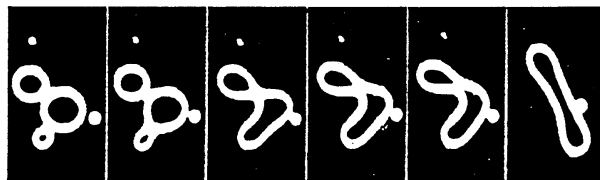

Fusion of a liposome

$0.71 \mathrm{sec}$

Fig. 16 リポソームの融合過程

れる様々な形を組み合わせることによって作るてとが出 来るはずです．いいかえれば膜器官の形態は脂質膜がも あっている本来の能力が発揮されたものだといえます.

リポソームは最近, 医学的応用をめぐってにぎやかに なってきています8).一方では膜中の脂質分子間に架橋 を入れた高分子化ポリソームが注目を浴びています9).

これらの研究に抢いても溶液中の動的なリポソームの形 態を研究するてとが不可欠になってくるあのと思われま す.とてで順次的多形変換の様子とリポソームの分裂 (Fig. 15) や融合 (Fig. 16) の過程を映画で見ていただ きます. ( この映画の部分は講演録から除きました).

御清聴ありがとうございました.

\section{文献}

1) O. Lehmann : "Flüssige Kristalle" Verlag von Wilhelm. Engelmann, Leipzig (1904) pp 254

2) H. Hotani : J. Mol. Biol., 178, 113 (1984).

3) 宝谷紘一：生体の科学, 36, 523 (1985).

4) P. B. Canham: J. Theoret. Biol., 26, 61 (1970)

5) B. Bull "Red Cell Shape" eds. M. Bessis, R. Weed, P. Leblond, Springer-Verlag, New York (1973) pp115.

6) T. Kunitake, Y. Okahata, M. Shimomura, S. Yasunami, K. Takarabe: J. Am. Chem. Soc., 103, 5401 (1981).

7) N. Nakashima, S. Asakuma, T. Kunitake, H. Hotani:Chem. Lett., 1984, 227 (1984).

8) 坂野喜子, 野沢義則: 膜, 10, 235 (1985).

9) 北野博已: 膜, 10, 279 (1985) 